\title{
The Returns of Recognition: Ngarinyin Experiences of Native Title, Encounter and Indeterminacy in the Kimberley Region of Northern Australia
}

\author{
Cameo Dalley \\ Deakin University
}

\begin{abstract}
This article explores a contemporary politics of recognition as it relates to Ngarinyin Aboriginal people of the Northern Kimberley region of Western Australia. I focus on the reflections and experiences of a Ngarinyin man, 'the Alchemist', who was involved in a native title claim across the region during the 2000s. Through ethnographic examples drawn from along the Gibb River Road, I show that time on country is animated by unexpected encounters imbued with interpersonal recognition and indeterminacy. These encounters involve non-Aboriginal people (including tourists) and non-human animals: allies who are co-opted at a time when people's intimate knowledge of country is becoming further attenuated. This article contributes to a growing literature on Aboriginal people's perceptions of and experiences in country in post-native title contexts.
\end{abstract} Key words: Northern Kimberley, Aboriginal, recognition, indeterminacy, native title.

\section{INTRODUCTION: THE RETURNS OF RECOGNITION}

This article draws on research with Ngarinyin Aboriginal people whose primary orientations are to lands and waters in the remote Northern Kimberley in Western Australia, a territory traversed by the Gibb River Road. Though most Ngarinyin people now live in towns and communities located on the periphery of Ngarinyin country, a dwindling number live in small settlements along what is affectionately referred to as 'the Gibb'. A continual reduction in government services provided in locations on country and the recent shift in government approaches to the funding of remote communities have compounded the tenuousness of Aboriginal people's residence on country. A 2012 report published by the Wilinggin Aboriginal Corporation (WAC), which is the relevant entity representing Ngarinyin people, summarised this situation: 'many Ngarinyin people do not live on or visit country' and 'many children have never been to their ancestral lands' (WAC 2012:30). However, rather than focusing on the cultural politics of the articulation of Ngarinyin

This is the author manuscript accepted for publication and has undergone full peer review but has not been through the copyediting, typesetting, pagination and proofreading process, which may lead to differences between this version and the Version of Record. Please cite this article as doi: 10.1002/ocea.5208

This article is protected by copyright. All rights reserved. 
identities and interactions off Ngarinyin country, such as in the towns of Derby, Wyndham and Mowanjum, in this article I focus more specifically on the value that visits to country and being on country holds for those living away from it. Specifically, I describe the ways in which recognition and indeterminacy were read through encounters with kardiya (non-Indigenous people in local parlance) and non-human animals on Ngarinyin country.

The majority of my road trips along the Gibb have involved a senior Ngarinyin man, aged in his $60 \mathrm{~s}$, whom I call 'the Alchemist'. As he has been for other researchers, the Alchemist has been my key interlocutor in the Kimberley since I commenced fieldwork in the region in 2013. As I will explain further below, the man's social status has developed through a series of life experiences, including the key role that he played in a native title claim covering much of the Northern Kimberley during the 2000s.

In interpreting the active involvement of Aboriginal people in native title claims, two interrelated observations come to the fore. The first is that the processes of gaining formal recognition act as a source of identity affirmation, in that it affirms Aboriginal people's pre-existing and underlying relationship to country. To use Taylor's (1994) phrasing, this involves a 'fusing of horizons', from one's sense of self as an owner of country, to a recognition as such by others. This affirmation comes as much from within the Aboriginal polity as outside it. A related aspect of this formal country-based recognition is the expectation that it will transform the intersubjective space in which relations to other residents are figured (Smith 2003). What often transpires for Aboriginal people is an optimism for different kinds of relations on country, both with kardiya and non-human animals. A second and related observation is that Aboriginal people find appealing the indeterminate character of this transformed relationality. This indeterminacy has been previously identified in the ways in which Aboriginal people interpret the world generally, but especially in relation to country (e.g. Keen 1994; Povinelli 1993; Rumsey 1994). As Smith and Morphy (2007a:4) have noted, though native title is often framed as providing certainty for the purposes of land use and development, Aboriginal people's interpersonal relationships and the continued coexistence of residents may be more properly described in terms of indeterminacy (see also Smith 2003:44).

\section{NATIVE TITLE AND THE POLITICS OF RECOGNITION}


A number of authors have critically engaged with the divergent experiences of Aboriginal people with and on country in the aftermath of native title claims, whereby Aboriginal rights and interests have been recognised under Australian law (Babidge 2010; Glaskin 2017; Vincent 2017a). Povinelli (2002) conceptualises land rights and native title in terms of the operation of a kind of 'cunning', highlighting the paradoxical nature of the process whereby the state draws in and transforms Aboriginal identities as a means of rendering them recognisable and legitimate. Anthropologists have been attentive to these processes, identifying both the difficulties for Aboriginal people in articulating their identities within state processes and the limitations of the processes in achieving expected outcomes (e.g. papers in Bauman and Glick 2012; Smith and Finlayson 1997; Smith and Morphy 2007b). These perspectives offer valuable insights into what is arguably Australia's most continuous and extensive project of Aboriginal recognition (Smith and Morphy 2007a:4).

Reflections on the native title process coincide with a national debate regarding forms of constitutional recognition and treaty making, and in a period when international Indigenous scholars' perspectives on the politics of recognition are achieving prominence (Busbridge 2018:137; Muldoon 2016). North American Indigenous scholars Glenn Coulthard (2014) and Audra Simpson (2014) offer the concept of 'refusal', seeking to unsettle the power dynamic that establishes a hierarchy between recogniser and the recognisee (Taylor 1994). For Simpson, refusal constitutes both an analytical frame for accounting for Kahnawà:ke Mowhawk experiences of settler-colonial recognition, and a methodological approach that she glosses as 'ethnographic refusal'. Simpson points to a limited set of examples in which Kahnawà:ke Mowhawk enact the forms of refusal that she envisages, such as people refusing to vote in elections (where voting is non-compulsory) and a man refusing to provide an identity card in a hospital when presenting for medical treatment (Simpson 2014:218). In the latter instance, Simpson reports that the man 'informed the medical doctor that he was a citizen of the Mowhawk nation and would rather die of a heart attack than identify himself as a citizen of any other nation'. In line with her broader methodological approach of 'ethnographic refusal', Simpson provides only brief sketches of these instances, rejecting anthropology's desire for knowledge of the Indigenous other as part of colonialism's broader project.

The term 'ethnographic refusal' was actually first used by Sherry Ortner (1995) to advocate for a different approach to the interpretation of forms of resistance in subaltern groups. Writing 
some twenty years apart, Ortner (1995) and Simpson (2014) envisage a different role for ethnography in the pursuit of their political projects. Ortner argues for ethnography as a means of countering monolithic cultural representations of subalterns, while Simpson strives for a repositioning of Indigenous people's sovereign voice, through a rejection of anthropology's ethnographic project. Such as been the importance of Coulthard and Simpson's voices in scholarly debates about recognition that others have described their intellectual emergence as, for example, 'a significant political and intellectual moment' (Balaton-Chrimes and Stead 2017:2). Nevertheless, when applied to the Australian context, the work of Coulthard and Simpson raises probing questions about the subjectivity and agency of those who are active participants in state-mandated projects of recognition (Merlan 2014, 2018). Indeed, when examining the Australian situation, what stands out is not so much 'Aboriginal resurgence' realised through a turning away (Coulthard) or 'refusal' (Simpson), but a committed involvement and embrace of the politics of recognition by Aboriginal people in Australia, both within the intra-Aboriginal world and in seeking forms of structural recognition from the state. This embrace is illustrated in Aboriginal involvement in land rights and native title processes, which have now seen hundreds of claims determined across the landmass, all requiring the active involvement of Aboriginal claimants (Altman and Markham 2015:134). ${ }^{1}$

I argue that it is especially difficult to reconcile critiques of state recognition with the affective responses that successful native title claims generate within Aboriginal claimants. The ceremonies that mark the formal determination of a claim, events attended by the Australian Federal Court Judge presiding on the claim and Aboriginal claimants, are triumphant and emotional occasions. The frequent lament at such ceremonies is not that the recognition is too meagre or inconsequential, but that the process has taken too long to achieve, and that some claimants have died in the interim (WAC 2012:10). Aboriginal people with ancestral connections to country located in the more settled parts of Australia have often been excluded from native title recognition on the basis that they have insufficient evidence to substantiate their claims. This exclusion most often results from the necessity to demonstrate forms of cultural continuity though the inability of many Aboriginal people to do so usually arises from colonial patterns of dispossession. Some Aboriginal groups who have been initially unsuccessful have subsequently spent hundreds of thousands of dollars to commission additional research in the hope of having their claims addressed 
or revisited by the Federal Court. For observers it is this evidentiary nature of native title, being 'the burden of proof' on Aboriginal people, which forms the major critique of native title as a form of recognition (Povinelli 2002; Trigger 2011).

Through involvement in native title claims over a number of years, I can recall many interactions with Aboriginal claimants which signaled their investment in the native title process. ${ }^{2}$ This investment is not just the product of individual aspirations but carries a sense of participation as a jural responsibility, both to country and to future generations of Aboriginal people. The sincerity with which Aboriginal people pursue and celebrate native title recognition has at times tempered my own cynicism, for what I have otherwise conceived of as native title's limited potential to have transformative impacts on the material conditions of Aboriginal people's lives (see also Asche and Trigger 2011:221). To be clear, it is not my intention to 'defend the institution of native title' (Vincent 2018), but to ask what it offers the Aboriginal people that appear so committed to it (see Martin 2018; Trigger 2011). Hence, the challenge as I see it is to bear in mind critiques of the politics of recognition, and to continue a parallel focus on what Smith and Morphy (2007a) have termed its 'social effects'. In particular, I consider engagement with native title as part of the strategies employed by Aboriginal people 'to manage the ongoing relationship between settler and Indigenous residents' (Strakosch and Macoun 2012:62). An important aspect of this 'relationship' is how experiences may vary as a product of policy decisions and social patterns influencing Aboriginal people's lives and of the kinds of relationality that are desired (see also Hinkson 2017). In remote Australia at least this includes the attenuation of relations to country and the diminishing opportunities for remote-living Aboriginal people to craft livelihoods on country largely as the result of government policy decisions (Glaskin 2018:314; Vincent 2017b:154).

\section{MOVING OFF NGARINYIN COUNTRY}

The processes by which both historic and contemporary policy decisions evacuate remote Australia of Aboriginal people and seek to contain them as residents in town settings, form an important background to this article. The colonial history of the Kimberley has meant that Ngarinyin people have experienced long periods of exposure to kardiya settlement, as has been extensively detailed (Idriess 1949; Jebb 2002; Redmond 2005; Sullivan 1996). Since the 1880s this has entailed almost continuous periods of settlement and resettlement of various parts of the Kimberley. Frontier 
violence and the massacres of Ngarinyin people contributed to the consolidation of people into missions, pastoral station camps and Aboriginal reserves (Owen 2016). Over much of the $20^{\text {th }}$ century a significant number of Ngarinyin people continued to live on their ancestral country, exchanging their labour for meagre wages and rations, working as station hands and in domestic roles (Jebb 2002). Downturns in the cattle industry, the advent of equal wages and the increased availability of social security benefits, meant that many Ngarinyin people moved off pastoral stations and into towns and communities from the 1960s onwards (Davis 2004:31; Jebb 2002:250; Sullivan 1996:10).

Though many Ngarinyin and kardiya view the mid $20^{\text {th }}$ century as somewhat of a 'golden age', it was settler colonial occupancy and the exploitation of Aboriginal people as underpaid or unpaid labour that enabled the pastoral industry to thrive (Sullivan 1996). As in other parts of Australia, the status assigned to pastoral work by Aboriginal people has resulted in 'Aboriginal recognition of the rights of pastoralists to occupy pastoral leases' (Davis 2004:25). The asymmetric nature of these relations and Aboriginal people's desire to engage in pastoral work provided the motivation for the establishment of Aboriginal pastoral enterprises along the Gibb during the 1980s and 1990s. In that period, the Indigenous Land Corporation (ILC) and the Aboriginal and Torres Strait Islander Corporation (ATSIC) undertook a targeted re-acquisition of stations on behalf of the Aboriginal Traditional Owners. However, the expansion of the Aboriginal pastoral estate, which Davis (2004:23) has called a 'quiet revolution', was short-lived. The lack of operational funding available to Aboriginal pastoralists combined with the 'derelict' nature of many of the stations' infrastructure, and depleted cattle herds meant that many struggled to be profitable (Davis 2004:26; Redmond 2007:84). It was also through the involvement of ATSIC during the 1980s that Ngarinyin elders successfully lobbied for the excision of land from pastoral leases for the communities of Dodnun, Imintji, Kupungarri, Ngallagunda, Prap Prap and Wingingare (WAC 2012:9). Most of these communities had previously existed as Aboriginal camps on stations, though the formal excision of land provided greater security. Many town-based Ngarinyin people returned to live on country, making it another 'mass movement' of Aboriginal people in the Kimberley (Sullivan 1996:26).

Paradoxically the pressures that have resulted in Ngarinyin people moving off country have shown no signs of abating in the period since the determination of a successful native title claim 
across the region in 2004 (Redmond 2007). In 2015, the Western Australia Government announced its intention to withdraw services from approximately 150 'unviable' remote communities, many located in the Kimberley. Such would be the impact of the withdrawal of services from those settlements that the announcement quickly became known Australia-wide as the "closure of communities'. Though the plan to close communities was later scuttled following public outcry, the attrition of services from remote communities has continued. In the Northern Kimberley, the number of Aboriginal people living along the Gibb has reduced in tandem with the decline in services, with more and more people relocating to the large community of Mowanjum and to the port towns of Derby and Wyndham. As WAC (2012:9) describes: 'For some families, living on country is not an option because their land is on pastoral leases, or lacks infrastructure such as roads. Work commitments or aspirations and the necessity to send their children to school keep them in regional centres'. Ngarinyin people that remain along the Gibb generally eke out an existence based on seasonal mobility between an outstation and town; living 'out bush' in the Dry season, and 'camping' (sometimes literally) with town-based kin during the Wet season. Across the Kimberley, the centralisation of services away from outstations and small communities and into towns and regional centres requires Aboriginal people to travel further to access health services, education and the various government agencies with whom they are required to routinely interact to ensure the receipt of welfare benefits. A common lament heard in relation to persons who have moved, such as those with medical conditions is, 'he in town now, poor bugger, too sick'.

Nevertheless, it is not only access to government services that draws Ngarinyin people into towns. As elsewhere, the opportunities to interact with a broader range of people, to escape the claustrophobic sociality of small communities, or to leave violent and difficult family situations means that towns sometimes offer an attractive respite, notably for women (Burke 2013; Coulehaun and Gaykamanu 2010). Expanded options for material living including greater choice in shopping for basic household goods, food and fuel provide an attractive contrast to the over-priced and understocked community stores in the region. Though government mantra suggests that Aboriginal people relocate from communities in order to access employment opportunities, the reality is that such towns usually have high rates of unemployment, particularly for unskilled or low skilled labour. In any case formerly remote living Aboriginal people are generally ill-equipped to access such opportunities as their skills and level of education leave them uncompetitive in what is already 
an over serviced workforce. Maintenance of kin relations within the Aboriginal polity also creates different values and expectations of paid employment to those of the broader population (AustinBroos 2006; Peterson 2013). While some observers equate the move out of predominately Aboriginal locales and into open towns as a kind of liberation, life in these places entails being subjected to a different intensity of governmentality (Cowlishaw 2004; Fisher 2013, 2015; Myers and Peterson 2016:3). In Kimberley towns, Aboriginal people's lives are disciplined by high levels of surveillance from police, child protective services, teachers and health care workers. These service providers, who are predominately kardiya, form part of an omnipresent gaze on the lives of town residents. In the East Kimberley where some Ngarinyin people live, Aboriginal people are also subject to a government-imposed welfare reform 'trial' (Klein and Razi 2017). The cumulative effect is that for most Ngarinyin people, town life rarely delivers the kind of life that was imagined. For some, a kind of stasis sets in. Long, drawn out phone calls from my Ngarinyin interlocutors relocated in towns regularly recount their boredom, describing life as 'slack' or 'too slack', meaning that there is little or nothing to occupy their time (see also Musharbash 2007).

In towns, relocated Aboriginal people also face the additional burden of being settled on other Aboriginal people's country, and thus are not entitled to claim the primary status of being a 'Traditional Owner' (Merlan 1998). For example, in the 2000s Redmond (2001) described how the small group of Ngarinyin people who lived at Wyndham assumed somewhat of an 'enclave' status among Balangarra people who made up the majority local Aboriginal population. The association of Ngarinyin people to Ngarinyin country has now become something of a lament. Both Ngarinyin and other co-resident Aboriginal people share the view that Ngarinyin people should be living on Ngarinyin country and that any other situation is an inversion of that predestined order. Being located at a distance from one's country creates significant requirements for travel, with many of the important meetings and social occasions involving travel of hundreds of kilometres. As well as recasting social relations in towns, longitudinal trends that indicate the urbanisation of Aboriginal people have ramifications for the kinds of experiences they have when making return visits to their country (Kearney 2018; Vincent 2017b).

At the time of its announcement, many protests about the closure of communities focused on emplaced relationships with land and the maintenance of culture, language and identity. As Ngarinyin people have articulated, 'as more and more people move away from country into town, 
modern-day distractions threaten the knowledge and practice of customary law and culture' (WAC 2012:34). This discourse, with its focus on the 'customary', has been shaped as part of an attempt by Aboriginal peoples to make their claims to land 'politically intelligible' against broader dispossessory processes ( $\mathrm{Li} 2010$ ). In spite of changes to Aboriginal personhood, landed-identities continue to be the primary marker of indigeneity across a number of settler nations including Australia (Merlan 2014:304; Trigger and Martin 2016). The vesting of social and cultural capital in remote places feeds romantic discourses that reproduce the idea that authentic Aboriginal selves are located in remote Australia (Bessire 2012:470). Yet, as other scholars describe for Aboriginal people in various parts of Australia, the attenuation of connections to country has had a range of impacts, particularly on cosmologies and personhood more generally (Burbidge 2015; Glaskin 2012, 2018; Kearney 2018; Vincent 2017a). Challenging 'nostalgic views' of Aboriginal personhood has meant moving beyond analyses which construct country as a cultural vestige, while at the same time elevating Aboriginal people's phenomenological and relational experiences (Hinkson 2017).

\section{NGARINYIN CLAIMS IN COUNTRY AND THE ALCHEMIST}

Ngarinyin people were some of the earliest in Australian history to pursue legal recognition of their underlying rights in country. In June 1983 a group of Ngarinyin people gathered at a station along the Gibb to form the Kumali Land Council, and to begin the process of seeking legal recognition of their rights in country (WAC 2012:9). As Alan Rumsey (1996:4) has explained, Ngarinyin people, together with Worrora and Wunumbal people, lodged a common-law land claim in the Australian High Court in July 1991, preceding what would become the historic Mabo decision handed down in June 1992. Later, Ngarinyin, Worrora and Wunumbal people were among the first to lodge a native title claim in Australia in 1996 under the then recently implemented Native Title Act 1993 (Cth). Covering some 67,000 square kilometres of the Northern Kimberley, Neowarra $v$ Western Australia [2003] FCA1402, took in much of the iconic Gibb River Road and adjoining pastoral stations. The claim was contested by a number of respondent parties including the Western Australia Government, and as an agreement could not be reached between the Aboriginal applicants and the dissenting parties, the claim shifted into trial proceedings in the late 1990s. As part of the process of hearing evidence, the Federal Court spent ten days in 2000 and 2001 visiting sites across the claim 
area, with Aboriginal witnesses giving on-country evidence alongside a number of experts. The successful determination of native title was made in 2004, with just under half of the claim area recognised as being 'exclusive possession', the strongest type of recognition available under the Act (Redmond 2007:79).

One of the men who gave evidence during the proceedings was the Ngarinyin man I refer to as the Alchemist. Unlike most of his contemporaries, the Alchemist was an avid consumer of music, literature and history and would often bring books to read on our journeys. It was partly because of his life trajectory that on one of our road trips he told me that he thought of himself as akin to the novelist Paulo Coelho's (1988) literary character of the Alchemist, in the international best seller of the same name. The man's self-identification as the Alchemist was perhaps a collapsing of two key characters that appear in the book; a young shepherd boy who dreams a prophecy of hidden treasure and travels to locate it, and an alchemist, who meets the boy at the end of his journey and makes it known that the treasure sought by the boy is located back in the place where he began his journey. As will become evident through the discussion that follows, the man's self-identification as the Alchemist highlights the way he narrates his life in the themes of destiny, travel and prophetic returns. For this Ngarinyin man, the narrative also clearly aligns with the notion that treasure (loosely defined) is vested in country, and in literal and symbolic returns to it. This realisation came to him more forcefully later in life following his involvement with the native title claim that encompassed Ngarinyin country (Redmond 2007).

The Alchemist was born on his Ngarinyin mother's country on Karunjie station (previously known as Pentecost Downs) at the eastern end of the Gibb River Road. His father was a partAboriginal man and regionally renowned stockman from Queensland who was at the time head stockman at Karunjie (Jebb 2002:126). The Alchemist's father was born in 1903 and worked for two well-known kardiya who had fought in the $10^{\text {th }}$ Australian Light Horse Regiment during World War I, and in the 1920s were granted pastoral leases along the Gibb as part of the soldier resettlement scheme (Jebb 2002:104). The pair are remembered by Aboriginal people as being notoriously cruel; forcibly taking Ngarinyin women and children for labour, as well as mounting punitive raids, including the slaughter of Ngarinyin people at Karunjie and nearby Gibb River Station, supposedly as retribution for the killing of cattle (Jebb 2002:111). The Alchemist's father was an imposing and authoritarian figure, with a somewhat ambiguous relationship with the local 
Ngarinyin people who camped at the station. Though he routinely prevented his son from visiting the Ngarinyin camp at Karunjie, the Alchemist continued to do so, maintaining close connections to his kin.

As a child, the Alchemist developed symptoms of leprosy and was sent some 600 kilometres to the west with his mother to live at the Derby Leprosarium, also known as Bungarun. From 1936 until 1986, Bungarun mainly housed Wunambal, Worrorra and Ngarinyin people with leprosy who had been sent from across the Kimberley, creating a unique cultural milieu (Jebb 2002:137). It was during his time at Bungarun that the Alchemist developed a unique command of regional Aboriginal languages, as well as knowledge and connection to the 'old people', now deceased Aboriginal ancestors. Later, the Alchemist returned to work on pastoral stations along the Gibb with his father, predominately at Karunjie. During this time many stations along the Gibb employed Aboriginal men as stockmen, forming a network of Aboriginal pastoral identities that extended across the Kimberley. Working alongside his father and other Aboriginal stockmen, the Alchemist routinely travelled the Gibb on horseback, mustering cattle between stations. Throughout his life the experience of being on Ngarinyin country meant that he was able to develop an intricate knowledge of it, as well as his own emplaced understanding of Ngarinyin people as belonging to country.

Though much of the time I have spent with the Alchemist has been at his current home of Wyndham, we have often travelled through the native title claim area along the Gibb River Road for funerals, meetings and once in order that I meet kin living in Mowanjum and Derby. It was also during these many trips that he bemoaned what he felt was the continuous need for him to travel across the region to attend the meetings convened by Aboriginal organisations, including local and regional native title entities established to hold native title rights and interests. As the Alchemist described to me, most of the time at meetings was spent discussing proposals for agreements with kardiya that would bring new developments on Ngarinyin country. During long, bone-jarring drives on dirt roads lasting up to eight hours, the Alchemist would narrate the surrounding landscape; the site of an accident, a good dinner spot, an unusual tree, a place where his car had broken down. Included in these notable features were places that the Federal Court and Aboriginal witnesses had stopped at during the native title claim in order to hear evidence, and sometimes camped overnight.

Over time, the Alchemist's recursive telling of stories associated with the native title claim communicated the endurance required for the process of collecting evidence, lodging the claim and 
the court's activities. Similarly, the Wilinggin Aboriginal Corporation (WAC) (2012:10) which was established to hold the native title rights and interests, recently described the claim process; 'People came together, taking time out of their busy lives, as they knew how important this was to them and their descendants. The lengthy trial process spanned three years, with 59 days of hearings'. The labour involved in the claim was vindicated by the sense of triumph when the outcome became known. A related commentary which indexed the Alchemist's pride about the eventual success of the claim was his attitude towards the kardiya who had worked on the claim. In particular the Alchemist mentioned an anthropologist, a linguist and land council staff, marveling at the hours of meticulous and dedicated work that they had contributed. One description included that the anthropologist had 'even' brought a laptop into the field, working late into the night to type up his notes. The labour of kardiya in the determination of Ngarinyin people's country was the source of considerable pride, and the man forcefully asserted that 'our people, Ngarinyin people, got to recognise them for that'. The forging of new interpersonal relationships through the process of gaining recognition was a cherished aspect of the experience. Though only one perspective, the Alchemist's figuring of kardiya as integral to the realisation of recognition for Ngarinyin people is influential because of his prominent status throughout the Kimberley. It is also indicative of the way in which native title is figured as establishing new kinds of relationships.

\section{RECOGNITION AND RELATIONS WITH KARDIYA}

The anthropologist Anthony Redmond (2001, 2005, 2007) has written much about relations between Ngarinyin people and co-resident kardiya, particularly along the Gibb where much of his research has taken place. In one strand of his research, Redmond (2005) focused on an historical instance in which Ngarinyin people living at a particular pastoral station had established a longterm relationship with members of a resident pastoral family. Redmond examines the processes by which Ngarinyin people at the station reconfigured kardiya, who at one time were conceptualised as strangers, into kin. It was the long-term and interdependent nature of this relationship that provided the basis of a particular kind of co-existence. Though Redmond (2005) described these relations in terms of 'mutual dependency', in the wake of the successful native title determination in 2004, he reflected on what he called the 'relative power imbalances which have prevailed for so long throughout the region and long set the tone of black and whitefella engagements' (2007:84). 
One noticeable change that Redmond (2007:84) observed was pastoralists locking station gates to prevent Aboriginal people from accessing their country, as against their rights to do so under legal provisions in the native title determination. During many trips along the Gibb between 2013 and 2017, the Alchemist and other Ngarinyin companions showed little inclination towards accessing pastoral stations, offering a variety of reasons for not doing so. One common observation was that the kardiya station managers were not known and that they did not know Aboriginal people, a product of the rapid turnover in ownership with many pastoral stations along the Gibb being bought, sold and sub-leased by large corporations. This included the Indigenous Land Corporation (ILC), Australian Wildlife Conservancy and the entrepreneur Kerry Stokes' investment company, Australian Capital Equity. What this meant is that Ngarinyin people could not be assured of interactions with kardiya station managers who appreciated or respected Ngarinyin relations to country and would agree to facilitate their access. The closing off to Ngarinyin people of these vast tracts of land has had the effect of condensing the possibilities for social production and reproduction to the road itself, and to a small number of locations deemed to be friendly (or at least not openly hostile) to Aboriginal people. One of these locations was Home Valley Station (HVS) at the eastern end of the Gibb River Road.

HVS is a former working cattle station purchased in 1999 by the Indigenous Land Corporation (ILC) through their tourism arm Voyages, on behalf of the Traditional Owners. HSV's facilities and operations reproduce much of the tourist encounter in the Kimberley which echo and celebrate the triumph of colonial pastoral expansion, while paying scant attention to the region's rich and well-documented Aboriginal history. ${ }^{3}$ Nevertheless the Alchemist had developed an amicable relationship with the HVS manager and staff, in large part because of visits that he had made there with ILC managers while devising a plan for development and management activities to take place at nearby Karunjie station. ${ }^{4}$ Though at various times some Ngaringyin people have expressed concern about the activities of the ILC, the Alchemist often spoke in positive terms of the employment and training opportunities that the developments could deliver for young people.

The Alchemist's status with HSV staff was evident during an overnight stay at the station in 2016. As we entered the bustling HVS Dusty Bar and Grill, one of the Station's many Indigenous trainees showed us to our table and we pulled back our heavy outdoor furniture chairs on the polished concrete. After consulting the menu, the Alchemist gestured for me to lean forward so that 
he could whisper. 'Over there,' he said, tilting his head. 'That's Merv Hughes.' Seated at the table next to us with a group of men was Mervyn 'Merv' Hughes, who was a renowned member of the Australian cricket team during the 1980s and 1990s. Hughes was instantly noticeable by his signature handlebar moustache and towering, bulky frame. As we sat eating our dinner the Alchemist recounted his memories of watching Hughes play cricket on the television and his notoriety for excessive alcohol consumption. During dinner the HSV Manager came to greet the Alchemist, the pair having formed an acquaintance over many visits to the station. The genesis of this acquaintance was the Alchemist's status within the native title claim and therefore with the ILC, which had led to him periodically being offered free accommodation and food at the station, including at night-time concerts to mark the opening and closing of the tourist season.

On this particular evening, the Manager asked the Alchemist if he could introduce him to Hughes, the Manager telling Hughes that the Alchemist was a 'local'. The term 'local' is used somewhat ambiguously (even awkwardly) by kardiya in the Kimberley, often used to denote a person's locally significant Aboriginal ancestry. Clearly flattered, the Alchemist shook hands with Hughes and the men briefly discussed Hughes' travel plans. The meeting with Hughes was clearly a highlight for the Alchemist and in the days that followed he described the encounter to his Aboriginal kin, recalling further details of Hughes' sporting prowess and marveling that he had travelled all the way to the Kimberley. What was particularly important was that the HSV Manager had singled out the Alchemist to introduce him to Hughes, a direct and public acknowledgement of his status as a 'local' with a specific relation to country.

In 2018, the Alchemist described to me over the phone another situation where he had been asked to accompany (mostly Aboriginal) school children and kardiya teachers from Wyndham on a day-long visit to a nearby working farm and tourist destination. The kardiya station owner was also a long-term friend of the Alchemist, and the men and the Alchemist's father had worked together at the Wyndham wharf during the 1970s. The men's relationship had emerged over periods of shared labour and co-residence around Wyndham, as the station owner explained during an interview in 2016:

Yeah, I think we just click. You know, when you meet somebody you click together and then it falls into place. Respect on both sides, I respect his family and his father and where he was bought up and he's the same for me I should imagine. 
The mention of 'his father' indexes the prominent position of the Alchemist's father within the racialised hierarchy of Kimberley society. In contrast, the kardiya teachers did not have a personal relationship with the Alchemist and his selection as a chaperone for their visit reflected his standing in the community as a mediator between Aboriginal people and kardiya. During the visit, the Alchemist told me that he was 'waited on hand and foot' by the school teachers, who prepared for him cups of tea, sandwiches and so on. Through the day he described that he 'never moved from my chair, like a member of parliament'.

The Alchemist's cultivation of acknowledgement when on his country was illustrated by a regular stop that we made at the commencement of a journey along the Gibb River Road. At the eastern end of the Gibb we would often break our journey at the top of a 'jump-up' that had a spectacular view across the iconic Cockburn Ranges. Also at the jump-up is a sign erected by the Wilinggin Aboriginal Corporation that states: 'You've Arrived in Our Country: Ngarinyin people's country'. The sign welcomes visitors, with the text appearing in both Ngarinyin and English. Sometime in 2016, a second sign was added underneath, providing information about 'Prescribed burning on Wilinggin Exclusive Possession Native Title Area'. Each time we arrived at the jumpup, the Alchemist would read the sign (and later both signs) aloud to me, and any proximate tourists who had stopped to take photographs. The jump-up was the last location for reliable mobile phone service before reaching the flood plains outside Derby, approximately 600 kilometres to the west. The Alchemist often made a flurry of last minute phone calls here, reminding kin that he was about to go out of reception and not to phone him. In this way the jump-up functioned as an important gateway in the Alchemist's social-spatial world.

As important as recognition were particular experiences where recognition was found lacking (nonrecognition) or where the kind of acknowledgement on offer amounted to misrecognition (Taylor 1994). As Taylor (1994:25) points out, those who have experienced nonrecognition or misrecognition 'can suffer real damage, real distortion' to their identities. The Alchemist had a generally favourable interpretation of tourists and derived a sense of pride in them coming to visit the Kimberley. During one trip in 2016 he described how what he called 'overseas kardiya', meaning tourists visiting from overseas, always acknowledged him on the road with a friendly hand gesture. These gestures ranged from the subtle lifting of the index and middle finger from the steering wheel, to a more sustained wave involving one entire hand and arm. 'Australian 
kardiya' the Alchemist told me, were less reliable, and when passing a car in which the occupants did not reciprocate his hand gesture he explained, 'Ah, got to be Australian kardiya, overseas kardiya wouldn't do that. That Australian kardiya already think they own the place.' The Alchemist's interpretation of the lack of a gesture towards him as related to kardiya assertion of ownership of country relates to Peace's (2013) description of hand gestures while driving in the Northern Territory. Peace described how in the Northern Territory, there was 'no necessarily alignment between the intent of the instigator and the respondent's interpretation', but that there was nonetheless 'nothing indiscriminate or random about them [hand gestures]' (2013:104). In the Alchemist's analysis, the lack of gestural reciprocation amounted not only to a nonrecognition, but also a de facto denial of his ownership of country (they 'think they own the place'). Regardless of the intention of other drivers, whether or not he was acknowledged was always experienced with reference to the racialised politics of country ownership, and was a routine part of the way that the Alchemist encountered others in the landscape.

Later on the same trip, the Alchemist and I came across a group of approximately a dozen middle-aged men standing alongside the Gibb, not far from where the road splits to head north to the community of Kalumburu or west towards Derby. The type of four-wheel drive vehicles parked along the road and the clothing worn by the men made them immediately identifiable as Australian tourists: they wore straw hats and board shorts and drank from cans of beer in coolers. As I slowed my Toyota to see if they had broken down or assistance was required, one of the men moved so as to be standing in the middle of the road, feigning the role of a traffic controller before moving slightly to one side and waving us on. Just as I began to accelerate, the Alchemist twisted his hand to give an informal hand gesture (a kind of wave), common among Kimberley Aboriginal people. The tourist misinterpreted the signal as the raising of an index finger, what he perceived to be a rude gesture. The man's facial expression immediately changed and he kicked the side of the car, two loud thuds echoing through the cabin. Such was the effect that I initially perceived the sound either to be a gunshot or 'blow-out' (punctured tire), causing me to shout with some alarm, 'What was that!' As we drove on, the Alchemist became increasingly agitated about the fact that his gesture of salutation had been so badly misrecognised and that the tourist had attempted, to act (albeit jovially) as a gatekeeper to him, a Traditional Owner. This experience underlines the fragility of face-to-face encounters where the norms guiding such behavior are open to variable interpretation. 
At play in each of these examples is Tully's (2004:85) idea of the 'intersubjective norms of mutual recognition' by which parties try to make themselves intelligible to one another. These norms include 'laws, rules, conventions or customs', all of which are read within a framework of intersubjective moments of mutual recognition.

\section{LOCATING INDETERMINACY}

In the previous section I described a number of exchanges between the Alchemist and kardiya that took place along the Gibb. In navigating encounters, the longevity of relationships was one of the factors that impacted the interpretation of events, and whether or not the Alchemist felt that he had been sufficiently recognised. In this section I discuss indeterminacy as another principle that determines the ways in which encounters were perceived. My interpretation of 'indeterminacy' draws on earlier work by anthropologists working across Northern Australia. In his analysis of relations between Aboriginal people and pastoralists in Cape York, Smith (2003:43) argues for the role of 'indeterminacy rather than determinacy', as the defining quality of interactions between Aboriginal and non-Aboriginal people, and the basis upon which to build 'meaningful coexistence'. This, he argues, is because of the vital place of indeterminacy within 'Aboriginal law and custom', a point also made by Keen (1994), Povinelli (1993) and Rumsey (1994).

In the way that the term 'indeterminacy' works, it defines a relationship between Aboriginal people and country where events are interpreted by what Povinelli (1993) aptly captures in the phrase 'might be something'. More than simply uncertainty, indeterminacy is a cultural principle that emerges out of what Merlan (1997:8) calls an 'epistemic openness' in the way that Aboriginal people determine 'relevance in the social production of meaning' (see also Smith 2003:41). Much of this 'openness' has been related to Aboriginal people's close relationships with the plants, animals and landscape features that comprise their dense place-worlds (Keen 1994; Peterson 2011). It is both openness and indeterminacy that allows Aboriginal people to interpret an unexpected encounter as presaging or announcing another event, and/or as being circumstantial happenstance.

Alan Rumsey (1994:116) describes how Ngarinyin people imbue features of the landscape with indeterminacy through various inscriptive practices, such that those features became 'a medium for the production and reproduction of meaning'. Rumsey's particular point was that between the 1970s and 1990s at the time that he was conducting fieldwork, in addition to the 
Dreaming and mythic memory, Ngarinyin people drew on their everyday lived experience to inscribe and re-inscribe their country. However, changed relations with government and the withdrawal of services to remote living Aboriginal people in the Kimberley region, a process which has continued to intensify, has meant that most Ngarinyin people have highly attenuated knowledge of country (WAC 2012:10). What this means is that indeterminacy is located not only in features in the landscape, as Rumsey set out, but increasingly in the encounters that Ngarinyin people have with others on country.

Given the processes which have resulted in the displacement of Ngarinyin people, being on country now more often means being remote and isolated from one's kin. This remoteness has a number of defining features, for example, the lack of mobile phone reception through much of the region means that people are unable to be in regular contact with kin, bringing to the fore face-toface interaction. As mentioned previously, pastoral stations that were once seen as places where Ngarinyin people could be received as visitors (however acrimoniously) are now sealed off. This has had the effect of increasing the physical distances between known social worlds. Related to this, encounters with others when on country, especially those classified as 'kin', are both unpredictable and uncommon. This contrasts to the interactional norms in towns and communities where face-toface meetings and phone-based communication with kin give shape to a reliable and constant social world. It is particularly in the absence of human kin that non-human animals are imaginatively drawn on as a means of repopulating and socialising the landscape.

In September 2016 I was traveling with the Alchemist on the Gibb River Road. Shortly after the turnoff to Karunjie station, the Alchemist suddenly gasped and shifted himself upright in his seat by grabbing the hand rail in the car. 'Slow down, slow down. I haven't seen this fella for long time. Go little bit closer. He must be a young one, you know. Don't scare him! They must still be out there breeding up, you know'. I slowly edged my Toyota Hilux forward. In front of us on the road was a young donkey. As we moved closer the donkey traversed the road backwards and forwards, as though engaging us in play. For five minutes we watched the donkey, him backing away from us each time we edged closer. The Alchemist took numerous photographs on his mobile phone and as we drove on along the road, he turned to me 'that one, oru marnerr-ngarri we say, for the ears, you know'. The significance of this encounter was not only to do with seeing the donkey, 
a relatively unusual occurrence in the Kimberley, but his engagement with us as an intersubjective moment of mutual recognition.

In the hour that followed the Alchemist explained how in his days as a stockman, teams of donkeys had been a celebrated part of the workforce, carting much needed supplies into areas that other animals were reticent to go on account of the rough physical terrain. He also recalled how in later years when their numbers in the wild had grown, donkeys had been herded into temporary yards and shot. Over the last three decades the Western Australia Government has resourced the aerial shooting of donkeys across the Kimberley region, with annual cull rates reaching into the thousands. Even now, the Alchemist told me, it was possible to find mounds of donkey bones in the landscape, places that he described as akin to where 'elephants go to die'. In the man's sentimental description of oru marnerr-ngarri, it was impossible for me not to recall the massacres of Ngarinyin people by early explorers and pastoralists across the Kimberley, historical events of which the Alchemist spoke often. This included notorious punitive expeditions by police in response to the killing of livestock by Aboriginal people (Owen 2016). In remembering the contribution of donkeys to the pastoral industry, and of their subsequent obliteration from the landscape, the Alchemist's narrative highlights that the unexpected nature of this encounter exemplified something of the fragility and unpredictability of life in the bush, as distinct from town.

For the rest of the day the Alchemist was in a jovial mood, and when we arrived at our destination he gleefully recounted to his Aboriginal kin the sighting of the donkey, poring over the images on his mobile phone. While at the station, the Alchemist also encountered the kardiya manager of the local Aboriginal Ranger group. Having overheard the Alchemist speaking with his kin, the manager asked where we had seen the donkey so that he could go and shoot (kill) it. Shifting tone, the Alchemist responded with some chagrin that the man should not shoot the donkey, and that he should 'let it be'. Months after the event, the Alchemist asked me a number of times if I remembered seeing the donkey and asked me to send to him the photographs that I had also taken on my mobile phone. In 2018 he telephoned to tell me that he had seen two wild donkeys on Karunjie station, emphasising that the 'young fella' (the donkey that we had seen previous) was not among them, but that he must be 'out there, somewhere'. What stood out about our earlier encounter with the donkey was its unexpectedness, and that its presence on country indicated the kind of perseverance valued by Aboriginal people. 
Anthropological literature has illustrated the often close associations between Aboriginal people and animals broadly thought of as non-native (Vaarzon-Morel 2010). In an article summarising this literature, David Trigger (2008) canvassed the many instances in which nonnative animals have been incorporated or excluded from Aboriginal cosmologies. For some animals in particular, this incorporation reflected 'a routine familiarity (especially among older persons) that has developed with the working horses, sheep, cattle, and dogs of the pastoral industry' (2008:637). This familiarity, which similarly applies to donkeys, means that such animals are often thought of by Aboriginal people as a resource, or sometimes kin (Trigger 2008:632; Vaarzon-Morel 2010:79). This contrasts with contemporary land management situations where Aboriginal people are often called upon to make decisions that would denote animals as either native or (problematically) 'feral', 'invasive', designations based largely on their negative impact on country in ecological terms.

While I contend that the Alchemist designated the donkey as an ally, as the number of Ngarinyin people involved in the pastoral industry decreases, there will likely be a range of different interpretations of these kinds of human-animal encounters. In Australia funding for land management generally follows successful native title claims, with most Aboriginal ranger groups established through Prescribed Body Corporates established under the Native Title Act (Cth). Whether or not encounters such as this one continue to be thought of as having indeterminate meaning, they will continue to provide contexts for negotiation and conversation within contemporary land management regimes.

\section{CONCLUSION}

At a time when a renewed focus on aspirations for Indigenous recognition has reanimated national debates in Australia, it is important to consider how earlier kinds of recognition have influenced the experiences that Aboriginal people have on country. Ngarinyin people have themselves identified the shifting nature of their experiences of and on country. The encounters described in this article are presented as they were experienced; fleeting comings together, each appearing coincidental, unlikely and fortuitous. In the shadow of what remains for Ngarinyin a successful native title claim, these moments hardly seem novel or to amount to the beginning of an era in which Ngarinyin people take a decisive role in establishing new kinds of relationships with 
kardiya. Nevertheless, it is within the context of the increased surveillance of Ngarinyin people's lives that time on country is interpreted as alive with possibility. The recasting and drawing in of proximate allies, both non-Aboriginal people and non-human animals, is part of the way in which Ngarinyin people continually socialise and resocialise their country. For the Alchemist these encounters form a relatively cohesive narrative that accords with his own sense of self, similar to the way in which Taylor (1994:67) described recognition as achieving a 'fusing of horizons'. For the Alchemist this fusing of horizons included being part of the successful native title claim over Ngarinyin country, something that he reflected on as a seminal achievement in his life trajectory.

In describing Ngarinyin experiences in the Kimberley, I contribute to a renewed interest in Aboriginal people's relations to country in view of contemporary developments in Aboriginal personhood (papers in Austin-Broos and Merlan 2018). Anthropologists discuss Aboriginal people's altered perceptions of animals or spirits and feelings of 'fear' or affection, reproducing the idea that experiences of country are predominately tied to cultural and spiritual values (Burbidge 2015; Eickelkamp 2017; Glaskin 2018; Kearney 2018; Vincent 2017b). The observations made in this article should be read alongside such contributions, where the value of time spent on country is in its potential to yield recognition and indeterminacy in relations with others.

My starting point in this article was to think about the pressures on Ngarinyin and other Aboriginal people to leave remote settlements and then to consider the kind of lives which might confront them as town residents. In towns, Aboriginal people are subject to ever-tightening circles of state surveillance and Ngarinyin find themselves living on other Aboriginal people's country. The movement of people off country and the shutting off of vast tracts of land to Aboriginal people via pastoral leases and their attendant management practices has had the effect of intensifying experience on the Gibb River Road itself. It is in these circumstances that Ngarinyin people equate being on country with kinds of recognition and indeterminacy otherwise unavailable. As the state forecloses on Ngarinyin people's lives on their country, indeterminacy is vital to the way people read encounters and maintain a sense of optimism for the future.

\section{ACKNOWLEDGEMENTS}

Fieldwork and research for this article was undertaken while I was the McArthur Postdoctoral Fellow in Anthropology at the University of Melbourne. Special thanks to the Alchemist and 
Christine McLachlan of the Wyndham Historical Society. Thanks to Melinda Hinkson, Eve Vincent, reviewers and particularly to Alan Rumsey for his generous feedback on this article in draft form.

\section{NOTES}

1. Altman and Markham (2015:134) estimated this to be ' 92 determinations of exclusive possession native title totalling over $752,000 \mathrm{~km}$; and 142 determinations of non-exclusive native title (that provide highly variable rights shared with other interests, often commercial pastoralism) covering 825,000 km'.

2. From 2004-2006 I was employed by an Aboriginal organisation who were pursuing a native title claim in the Gold Coast region. From 2011-2012 I worked intermittently for the Queensland State Government assessing anthropological 'connection reports', submitted as part of native title claims processes. I ran the Centre for Native Title Anthropology at the Australian National University from 2012-2015. In each of these positions I was in regular contact with Aboriginal claimants and the anthropologists employed to conduct research.

3. In this regard Home Valley Station is almost indistinguishable from the nearby resort at El Questro Station.

4. Karunjjie and Home Valley Stations comprise some of the ILC's largest holdings by area, at 273,941 ha and 248,939ha respectively.

5. From the translation kindly provided by Alan Rumsey: oru meaning 'his ear', marned meaning 'big' and ngarri meaning 'one' or 'big-eared one'. 


\section{REFERENCES}

ALTMAN, J. and F. MARKHAM 2015. Burgeoning Indigenous land ownership: Diverse values and strategic potentialities. In S. Brennan, M. Davis, B. Edgeworth and L. Terrill (eds) Native Title from Mabo to Akiba: A vehicle for change and empowerment? Annandale, NSW: Federation Press, pp. 125-142.

ASCHE, W. and D. TRIGGER. 2011. Native title research in Australian anthropology. Anthropological Forum 21(3):219-232.

AUSTIN-BROOS, D. 2006. 'Working for' and 'working' among Western Arrernte in Central Australia. Oceania 26(1):1-15.

and F. MERLAN (eds). 2018. People and Change in Indigenous Australia. Honolulu, HA: University of Hawai'i Press.

BABIDGE, S. 2010. Aboriginal Family and the State: The conditions of history. Surrey, UK: Ashgate.

BALATON-CHRIMES, S. and V. STEAD. 2017. Recognition, power and coloniality. Postcolonial Studies 20(1):1-17.

BAUMAN, T. and L. GLICK. 2012. The Limits of Change: Mabo and native title 20 years on. Canberra, ACT: Australian Institute of Aboriginal and Torres Strait Islander Studies.

BESSIRE, L. 2012. The politics of isolation: Refused relations as an emerging regime of Indigenous biolegitimacy. Comparative Studies in Society and History 54(3):467-498.

BUSBRIDGE, R. 2018. Multicultural Politics of Recognition and Postcolonial Citizenship: Rethinking the nation. London, UK: Routledge.

BURBIDGE, B. 2015. 'We are kangaroo, we have the owl': Linguistic and emotional clues of the meanings of the bush in changing Wiradjuri being and relatedness. The Australian Journal of Anthropology 26:414-427.

BURKE, P. 2013. Indigenous diaspora and the prospects for cosmopolitan orbiting: The Warlpiri case. Asia Pacific Journal of Anthropology 14(4):304-322.

COELHO, P. 1988. The Alchemist. San Francisco, CA: Harper.

COULEHAN, K. and W. GAYKAMANU. 2013. Family matters: YolKu women and children and rural-urban mobility. In C. Hansen and K. Butler (eds), Exploring Urban Identities and Histories. Canberra, ACT: Australian Institute of Aboriginal and Torres Strait Islander

This article is protected by copyright. All rights reserved. 
Studies, pp. 51-71.

COULTHARD, G. S. 2014. Red Skin White Masks: Rejecting the colonial politics of recognition. Minneapolis, MI: University of Minnesota Press.

COWLISHAW, G. 2004. Blackfellas, Whitefellas and the Hidden Injuries of Race. Carlton, VIC: Blackwell Publishing.

DAVIS, R. 2004. Aboriginal managers as blackfellas or whitefellas? Aspects of Australian Aboriginal cattle ownership in the Kimberley. Anthropological Forum 14(1):23-42.

EICKELKAMP, U. 2017. Finding spirit: Ontological monism in an Australian Aboriginal desert world today. HAU: Journal of Ethnographic Theory 7(1):235-264.

FISHER, D. 2013. Becoming the state in Northern Australia: Urbanisation, intra-Indigenous relatedness and the state effect. Oceania 83(3):238-258.

2015. An urban frontier: Respatialising government in remote Northern Australia. Cultural Anthropology 30(1):139-166.

GLASKIN, K. 2012. Anatomies of relatedness: Considering personhood in Aboriginal Australia. American Anthropologist 114(2):297-308.

. 2017. Crosscurrents: Law and society in a native title claim to land and sea. Perth, WA: University of Western Australia Press.

. 2018. Other-than-humans and the remaking of the social. Journal of the Royal Anthropological Institute 24:313-329.

HINKSON, M. 2017. Beyond assimilation and refusal: A Warlpiri perspective on the politics of recognition. Postcolonial Studies 20(1):86-100.

IDRIESS, I. 1949. One Wet Season. Sydney, NSW: Angus and Robertson.

JEBB, M. A. 2002. Blood, Sweat and Welfare: A history of white bosses and Aboriginal pastoral workers. Perth, WA: University of Western Australia Press.

KEARNEY, A. 2018. Intimacy and distance: Indigenous relationships to country in Northern Australia. Ethnos 83(1):172-191.

KEEN, I. 1994. Knowledge and Secrecy in an Aboriginal Religion: Yolngu of north-east Arnhem Land. Oxford, UK: Oxford University Press.

This article is protected by copyright. All rights reserved. 
KLEIN, E. and S. RAZI. 2017. The cashless debit card trial in the East Kimberley. CAEPR Working Paper 121. Canberra, ACT: Centre for Aboriginal Economic Policy Research, ANU.

LI, T. 2010. Indigeneity, capitalism, and the management of dispossession. Current Anthropology 51(3):385-414.

MARTIN, R. J. 2018. Review of “"Against Native Title”: Conflict and Creativity in Outback Australia' by Eve Vincent and 'Crosscurrents: Law and society in a native title claim to land and sea' by Katie Glaskin. Australian Book Review May 2018, No. 401.

MERLAN, F. 1997. Fighting over country: Four commonplaces. Smith, D. E. and J. Finlayson (eds) Fighting Over Country: Anthropological perspectives. Canberra, ACT: ANU Press, pp. 1-14.

1998. Caging the Rainbow: Place, politics and agency in a north Australian town. Honolulu, HA: University of Hawai'i Press.

2014. Recent rituals of Indigenous recognition in Australia: Welcome to Country. American Anthropologist 116(2):296-309.

. 2018. Dynamics of Difference in Australia: Indigenous past and present in a settler country. Philadelphia: University of Pennsylvania Press.

MULDOON, P. 2016. The failure of 'recognition'. Arena Magazine 142:17-20.

MUSHARBASH, Y. 2007. Boredom, time and modernity: An example from Aboriginal Australia. American Anthropologist 109(2):307-317.

MYERS, F. and N. PETERSON 2016. The origins and history of outstations as Aboriginal life projects. In N. Peterson and F. Myers (eds) Experiments in Self-Determination: Histories of the outstation movement in Australia. Canberra, ACT: ANU Press, pp. 1-22.

ORTNER, S. 1995. Resistance and the problem of ethnographic refusal. Comparative Studies in Society and History 37:173-193.

OWEN, C. 2016. 'Every Mother's Son is Guilty': Policing the Kimberley frontier of Western Australia 1882-1905. Perth, WA: UWA Publishing.

PEACE, A. 2013. The phatic finger: Public gesture and shared meaning on the highways of the Australian outback. The Australian Journal of Anthropology 24:99-114.

This article is protected by copyright. All rights reserved. 
PETERSON, N. 2011. Is the Aboriginal landscape sentient? Animism, the new animism and Warlpiri. Oceania 81(2):167-179.

2013. On the persistence of sharing: Personhood, asymmetrical reciprocity, and demand sharing in the Indigenous domestic moral economy. The Australian Journal of Anthropology 24:166-176.

POVINELLI, E. 1993. 'Might be something': The language of indeterminacy in Australian Aboriginal land use. Man 28(4):679-704. . 2002. The Cunning of Recognition: Indigenous alterities and the making of Australian multiculturalism. Durham: Duke University Press.

REDMOND, A. 2001. Rulug wayirri: Moving kin and country in the Northern Kimberley. Unpublished PhD thesis, University of Sydney.

- 2005. Strange relatives: Mutualities and dependencies between Aborigines and pastoralists in the Northern Kimberley. Oceania 75(3):234-246.

2007. Some initial effects of pursuing and achieving native title recognition in the Northern Kimberley. In B. R. Smith and F. Morphy (eds), The Social Effects of Native Title: Recognition, translation and co-existence. Canberra, ACT: ANU Press, pp. 79-90. RUMSEY, A. 1994. The Dreaming, human agency and inscriptive practice. Oceania 65(2):116130.

1996. Aspects of native title and social identity in the Kimberleys and beyond. Australian Aboriginal Studies 1:2-10.

SIMPSON, A. 2014. Mowhak Interruptus: Political life across the borders of settler states. Durham, NC: Duke University Press.

SMITH, B. 2003. Wither 'certainty'? Coexistence, change and land rights in Northern Queensland. Anthropological Forum 13(1):27-48.

SMITH, B. R. and F. MORPHY. 2007a. The Social Effects of Native Title: Recognition, translation, coexistence. In B. R. Smith and F. Morphy (eds) The Social Effects of Native Title: Recognition, translation, coexistence. Canberra, ACT: ANU Press, pp. 1-30. -. (eds). 2007b. The Social Effects of Native Title: Recognition, translation, coexistence. Canberra, ACT: ANU Press. 
SMITH, D. E. and J. FINLAYSON (eds) 1997. Fighting Over Country: Anthropological perspectives. Canberra, ACT: ANU Press.

STRAKOSCH, E. and A. MACOUN 2012. The vanishing end point of settler colonialism. Arena Journal 37:40-85.

SUlliVAN, P. 1996. All Free Man Now: Culture, community and politics in the Kimberley region, north-western Australia. Canberra, ACT: Australian Institute of Aboriginal and Torres Strait Islander Studies.

TAYLOR, C. 1994. The politics of recognition. In A. Guttman (ed) Multiculturalism: Examining the politics of recognition. Princeton, NJ: Princeton University Press, pp. 25-73.

TRIGGER, D. 2008. Indigeneity, ferality, and what 'belongs' in the Australian bush: Aboriginal responses to 'introduced' animals and plants in settler-descendant society. Journal of the Royal Anthropological Institute 14:628-646.

. 2011. Anthropology pure and profane: The politics of applied research in Aboriginal Australia. Anthropological Forum 21(3):233-255.

TRIGGER, D. and R. MARTIN. 2016. Place, indigeneity, and identity in Australia's Gulf Country. American Anthropologist 118(4):824-837.

TULLY, J. 2004. Recognition and dialogue: The emergence of a new field. Critical Review of International Social And Political Philosophy 7(3):87-88.

VAARZON-MOREL, P. 2010. Changes in Aboriginal perceptions of feral camels and of their impacts and management. The Rangeland Journal 32:73-85.

VINCENT, E. 2017a. 'Against Native Title': Conflict and creativity in outback Australia. Canberra, ACT: Aboriginal Studies Press.

2017b. Fear and wonder out bush: Engaging a critical anthropological perspective on Indigenous alterity. Journal of Religious and Political Practice 3(3):152-167.

. 2018. Letter to the Editor: A new anthropology. Australian Book Review June-July 2018, No. 402.

WILINGGIN ABORIGINAL CORPORATION. 2012. Wilinggin Healthy Country Plan- Looking After Ngarinyin Country 2012-2022. Derby, WA: WAC.

This article is protected by copyright. All rights reserved. 


\section{University Library}

\section{- M M N E R VA A gateway to Melbourne's research publications}

Minerva Access is the Institutional Repository of The University of Melbourne

\section{Author/s:}

Dalley, C

Title:

The Returns of Recognition: Ngarinyin Experiences of Native Title, Encounter and Indeterminacy in the Kimberley Region of Northern Australia

Date:

2018-11-01

\section{Citation:}

Dalley, C. (2018). The Returns of Recognition: Ngarinyin Experiences of Native Title, Encounter and Indeterminacy in the Kimberley Region of Northern Australia. OCEANIA, 88 (3), pp.360-376. https://doi.org/10.1002/ocea.5208.

Persistent Link:

http://hdl.handle.net/11343/284801 